\title{
Karyological study on 12 species of the genus Taraxacum (Asteraceae) grown in Turkey
}

\begin{abstract}
Gürdal, B. \& Özhatay, N.: Karyological study on 12 species of the genus Taraxacum (Asteraceae) grown in Turkey. [In Kamari, G., Blanché, C. \& Siljak-Yakovlev, S. (eds), Mediterranean plant karyological data - 28]. - Fl. Medit. 28: 429-439. doi:10.7320/FlMedit28.429
\end{abstract}

The somatic chromosomes and karyotypes of 12 Taraxacum species were determined. All studied species were collected from natural habitats in Marmara Region, NW Turkey. The chromosome numbers of Taraxacum aznavourii $(2 n=24), T$. gracilens $(2 n=24), T$. hyberniforme $(2 n=32)$ and T. pseudobrachyglossum $(2 n=24)$ are reported here for the first time. The basic chromosome number was found as $\mathrm{x}=8$ and all the examined taxa are triploid or tetraploid. All the examined species of the sections Erythrosperma and Palustria are triploids $(2 n=3 \mathrm{x}=24)$, while of the section Scariosa all are tetraploids ( $2 n$ $=4 \mathrm{x}=32$ ), with the exception of T. minimum, which is both triploids and tetraploids. The detailed karyotype features of the 12 Taraxacum species are also presented.

Keywords: Compositae, chromosome numbers, karyotype, Marmara Region.

\section{Introduction}

The genus Taraxacum Wiggers is widely distributed in various habitats around the world. The west and central Asian regions are the ancestral centre of Taraxacum. The highest species and character diversities of this genus are found especially in Turkey, Iran, Afghanistan, the West Himalayas, North-Central China and the Southern Caucasus (Richards 1973).

Taraxacum species could undergo apomixis or sexual reproduction. Approximately 90\% of Taraxacum species are apomictic. Generally, sexual Taraxacum species are diploid and apomictic species are polyploid (Richards 2003). On the other hand some tetraploids of the section Piesis are found to be sexual by Kirschner \& al. (1994). In cases where apomictic and diploid sexual plants co-exist, the sexual species differ from the apomicts in size (Valentine \& Richards 1967).

Diploid and apomictic species commonly co-exist in Taraxacum populations in Central Europe. In Europe, the Netherlands is the northern distribution limit for sexual species; polyploidy apomicts are present at higher latitudes (Dijk van 2003; Dijk Van \& al. 2009).

According to Kirscher \& al. (1994), sexual Taraxacum species have a limited geographical distribution. Taraxacum serotinum (Waldst. \& Kit.) Fisch. (sect. Dioszegia) and T. 
bessarabicum (Hornem.) Hand.-Mazz. (sect. Piesis) are the only sexual species with a wide distribution.

Classifying Taraxacum is complicated given the similar morphologies of species within this genus and the presence of apomixes and sexual reproduction (Kirschner \& Štěpánek 1996, 2012). In these respect karyological data are useful for systematic classification of Taraxacum.

In Turkey, the genus Taraxacum is represented by 57 taxa, 18 of which are endemic. These taxa are grouped into 12 sections: Dioszegia, Erythrocarpa, Erythrosperma, Macrocornuta, Oligantha, Orientalia, Palustria, Piesis, Primigenia, Scariosa, Sonchidium, and Taraxacum. The chromosome numbers of 30 Taraxacum species occurring in Turkey are recorded in the literature (Doll 1975, 1976b; Richards 1968, 1969; Gedik \& al. 2014; Kirschner \& Stepanek 1985, 1998; Drabkova \& al. 2009). Among these species, seven are diploid $(2 n=2 \mathrm{x}=16), 12$ are triploid $(2 n=3 \mathrm{x}=24)$, four are tetraploid $(2 n=4 \mathrm{x}=32)$, one is hexaploid $(2 n=48)$, and six species have two ploidy levels are recorded for other. The chromosome numbers of almost all Taraxacum species from Turkey have been counted by Doll $(1975,1976 \mathrm{a})$. The species mentioned above were collected by Prof. K. Walther from West Anatolia.

The aim of this study is to determine the chromosome number and karyotype features which are important to indicate apomixis or sexual reproduction, of 12 Taraxacum species from Turkey.

\section{Sect. Erythrosperma}

1943. Taraxacum aznavourii Soest $-2 n=3 \mathrm{x}=24$ (Figs $1 \mathrm{~A} \& 2 \mathrm{~A})$.

Tu: A2(A) Bursa: Uludağ, Kirazlı yayla, 1363 m, 20 Sept 2013, B. Gürdal 169-16, H. Gürdal (ISTE 101782).

Taraxacum aznavourii is an endemic taxon of the Turkish flora. The chromosome number of this species is $2 n=24$, triploid. Its karyotype formula is $2 n=3 \mathrm{x}=16 \mathrm{~m}+2 \mathrm{~m}$-SAT $+6 \mathrm{sm}=24$. Its chromosome lengths range between from 1.35 to $2.81 \mu \mathrm{m}$. Its $\mathrm{M}_{\mathrm{CA}}$ and $\mathrm{CV}_{\mathrm{CL}}$ values are 20.18 and 19.343, respectively (Table 1). The present study is the first report of the chromosome number and karyotype of this species.

1944. Taraxacum buttleri Soest $-2 n=3 \mathrm{x}=24$ (Figs 1B \& 2B).

Tu: A3 Sakarya: Taraklı, Karagöl yaylası yolu, 1114 m, 18 May 2014, B. Gürdal 716-54, M. Koçyiğit, N. \& E. Özhatay (ISTE 102545).

The chromosome number of this species is $2 n=24$, triploid. Its karyotype formula is $2 n$ $=3 \mathrm{x}=20 \mathrm{~m}+1 \mathrm{~m}-\mathrm{SAT}+3 \mathrm{sm}=24$. Its chromosome lengths range from 0.50 to $0.99 \mu \mathrm{m}$. Its $\mathrm{M}_{\mathrm{CA}}$ and $\mathrm{CV}_{\mathrm{CL}}$ values are 11.43 and 22.541, respectively (Table 1). This species was previously reported also as a triploid $(2 n=24)($ Doll 1976b). 
1945. Taraxacum gracilens Dahlst. $-2 n=3 \mathrm{x}=24$ (Figs 1C \& 2C).

Tu: A2(A) Bursa: Uludağ, Kirazlı yayla civarı, 1505 m, 26 May 2013, B. Gürdal 160-16, H. Gürdal (ISTE 101779).

The chromosome number of Taraxacum gracilens is $2 n=24$, triploid. Its karyotype formula is $2 n=3 \mathrm{x}=18 \mathrm{~m}+6 \mathrm{sm}=24$. Its chromosome lengths range from 1.12 to 2.12 $\mu \mathrm{m}$. Its $\mathrm{M}_{\mathrm{CA}}$ and $\mathrm{CV}_{\mathrm{CL}}$ values are 22.98 and 18.141, respectively (Table 1). The present study is the first to report the chromosome number and karyotype of this species.

1946. Taraxacum pseudobrachyglossum Soest $-2 n=3 \mathrm{x}=24$ (Figs 1D \& 2D).

Tu: A1(E) Tekirdağ: Hayrabolu, Ortaca’ya giderken, 3 km kala, 158 m, 22 Apr 2014, B. Gürdal 583-59, M. Koçyiğit (ISTE 102404).

The chromosome number of this endemic species is $2 n=24$, triploid. The karyotype consists of $2 n=3 \mathrm{x}=24 \mathrm{~m}$ chromosomes. Its chromosome lengths range from 1.07 to $1.72 \mu \mathrm{m}$. Its $\mathrm{M}_{\mathrm{CA}}$ and $\mathrm{CV}_{\mathrm{CL}}$ values are 5.97 and 15.365 , respectively (Table 1). The present study is the first to report the chromosome number and karyotype of this species.

1947. Taraxacum turcicum Soest $-2 n=3 \mathrm{x}=24$ (Figs $1 \mathrm{E} \& 2 \mathrm{E})$.

Tu: A2(A) Bursa: Uludăg, Karabelen piknik alanı, 1359 m, 26 May 2013, B. Gürdal 14016, H. Gürdal (ISTE 101772).

The chromosome number of the endemic Taraxacum turcicum is $2 n=24$, triploid, as previously reported by Doll (1975). Its karyotype formula is: $2 n=3 \mathrm{x}=13 \mathrm{~m}+2 \mathrm{~m}-\mathrm{SAT}+$ $9 \mathrm{sm}=24$. Its chromosome lengths range from $1.16 \mu \mathrm{m}$ to $3.03 \mu \mathrm{m}$. Its $\mathrm{M}_{\mathrm{CA}}$ and $\mathrm{CV}_{\mathrm{CL}}$ values are 23.53 and 30.667 , respectively (Table 1).

1948. Taraxacum waltheri $\mathrm{R}$. Doll $-2 n=3 \mathrm{x}=24$ (Figs $1 \mathrm{~F} \& 2 \mathrm{~F})$.

Tu: A3 Sakarya: Sapanca gölü güneyi, S.Ü. Kırkpınar MYO arkasında mesire alanı, 37 m, 17 Apr 2015, B. Gürdal 845-41, H. Gürdal (ISTE 107341).

The chromosome number of this endemic species is $2 n=24$, triploid, as previously reported by Doll (1976b). Its karyotype formula is: $2 n=3 \mathrm{x}=20 \mathrm{~m}+1 \mathrm{~m}-\mathrm{SAT}+3 \mathrm{sm}=24$. Its chromosome lengths range from 1.10 to $2.29 \mu \mathrm{m}$. Its $\mathrm{M}_{\mathrm{CA}}$ and $\mathrm{CV}_{\mathrm{CL}}$ values are 16.28 and 21.034, respectively (Table 1 ). 


\section{Sect. Palustria}

1949. Taraxacum scaturiginosum $\mathrm{G}$. E. Haglund $-2 n=3 \mathrm{x}=24$ (Figs $1 \mathrm{M} \& 2 \mathrm{M})$.

Tu: A1(E) Tekirdağ: Hayrabolu, Emiryakuplu'dan Ortaca'ya 6 km kala, 141 m, 22 Apr 2014, B. Gürdal 579-59, M. Koçyiğit (ISTE 102400).

The chromosome number of this species is $2 n=24$, triploid. Its karyotype formula is given as $2 n=3 \mathrm{x}=24$ metacentric chromosomes. Its chromosome lengths range from 1.02 to $2.02 \mu \mathrm{m}$. Its $\mathrm{M}_{\mathrm{CA}}$ and $\mathrm{CV}_{\mathrm{CL}}$ values are 9.09 and 25.819 , respectively (Table 1 ). The chromosome number of this species has been previously reported as $2 n=3 \mathrm{x}=24$ and $2 n$ $=4 \mathrm{x}=32$ (Rice \& al. 2014; Richards 1969).

\section{Sect. Scariosa}

1950. Taraxacum aleppicum Dahlst. $-2 n=4 \mathrm{x}=32$ (Figs $1 \mathrm{G} \& 2 \mathrm{G}$ ).

Tu: A1 (A) Çanakkale: Çan, Kocayayla çık1 ${ }^{\circ}$, mera, 306 m, 2 Nov 2013, B. Gürdal 36217, M. Koçyiğit (ISTE 102302).

The chromosome number of this species is $2 n=32$, tetraploid, as previously reported by Doll (1976b). Its karyotype formula is $2 n=4 \mathrm{x}=28 \mathrm{~m}+4 \mathrm{sm}=32$. Its chromosome lengths range from 0.67 to $1.49 \mu \mathrm{m}$. Its $\mathrm{M}_{\mathrm{CA}}$ and $\mathrm{CV}_{\mathrm{CL}}$ values are 11.86 and 21.649, respectively (Table 1$)$.

1951. Taraxacum hellenicum Dahlst. $-2 n=4 \mathrm{x}=32$ (Figs $1 \mathrm{H} \& 2 \mathrm{H})$.

Tu: B1 Çanakkale: Evciler-Çavulu arası, Çavulu'ya 3 km kala, 332 m, 3 Nov 2013, B. Gürdal 427-17, M. Koçyiğit (ISTE 102324).

The chromosome number of this species is $2 n=32$, tetraploid, as previously reported by Doll (1976b). Its karyotype formula is $2 n=4 \mathrm{x}=30 \mathrm{~m}+2 \mathrm{~m}-\mathrm{SAT}=32$. Its chromosome lengths range from 1.15 to $2.38 \mu \mathrm{m}$. Its $\mathrm{M}_{\mathrm{CA}}$ and $\mathrm{CV}_{\mathrm{CL}}$ values are 8.99 and 19.631 , respectively (Table 1).

1952. Taraxacum hyberniforme Soest Dahlst. $-2 n=4 x=32$ (Figs 1 I \& 2I).

Tu: A1 (A) Çanakkale: Lapseki, Balcılar-Umurbey yolu, Balcılar'dan $1 \mathrm{~km}$ sonra, çam altı, 240 m, 2 Nov 2013, B. Gürdal 379-17, M. Koçyiğit (ISTE 102310).

The chromosome number of this species is $2 n=32$, tetraploid. Its karyotype formula is $2 n=4 \mathrm{x}=27 \mathrm{~m}+5 \mathrm{~m}-\mathrm{SAT}=32$. Its chromosome lengths range from 1.36 to $2.62 \mu \mathrm{m}$. Its 
$\mathrm{M}_{\mathrm{CA}}$ and $\mathrm{CV}_{\mathrm{CL}}$ values are 7 and 20.316, respectively (Table 1). The present study is the first report of the chromosome number and the karyotype of Taraxacum hyberniforme.

1953. Taraxacum hybernum Steven $-2 n=4 \mathrm{x}=32$ (Figs $1 \mathrm{~J} \& 2 \mathrm{~J})$.

Tu: A1 (A) Çanakkale: Bayramiç, Karaibrahimler'den Cazgırlar'a giderken $1 \mathrm{~km}$ kala, 383 m, 2 Nov 2013, B. Gürdal 405-17, M. Koçyiğit (ISTE 102319).

The chromosome number of this species is $2 n=32$, tetraploid. Its karyotype consists of $2 n=4 \mathrm{x}=22 \mathrm{~m}+2 \mathrm{~m}-\mathrm{SAT}+8 \mathrm{sm}=32$ chromosomes. Its chromosome length range between 1.66 and $2.98 \mu \mathrm{m}$. Its $\mathrm{M}_{\mathrm{CA}}$ and $\mathrm{CV}_{\mathrm{CL}}$ values are 14.86 and 16.324 , respectively (Table 1 ). A previous study reported the chromosome number of this species as $2 n=24$ and $2 n=32$ (Doll 1975).

1954. Taraxacum minimum (Brig. ex Guss.) N. Terracc. $-2 n=3 \mathrm{x}=24$ (Figs $1 \mathrm{~K} \& 2 \mathrm{~K}$ ) $\& 2 n=4 \mathrm{x}=32$ (Figs $1 \mathrm{~L} \& 2 \mathrm{~L})$.

Tu: A2 (A): Yalova: Selimiye, Onno Tunç anıtı civarı, çayırlık, 716 m, 25 Oct 2013, B. Gürdal 233-77, M. Koçyiğit (ISTE 101811). - Figs 1K \& 2K.

- A1 (A) Çanakkale: Ezine, Gökçebayır'dan Mecidiye'ye 3 km kala, zeytinlik arası, 125 m, 3 Nov 2013, B. Gürdal 448-17, M. Koçyiğit (ISTE 102330). - Figs 1L \& 2L

Two polyploidy levels (triploid and tetraploid) are obtained for different populations. The chromosome number of the population from Yalova is given as $2 n=32$, tetraploid. Its karyotype formula is $2 n=4 \mathrm{x}=32=19 \mathrm{~m}+5 \mathrm{~m}$-SAT $+8 \mathrm{sm}=32$. Its chromosome lengths range from 1.06 to $3.21 \mu \mathrm{m}$ and its $\mathrm{M}_{\mathrm{CA}}$ and $\mathrm{CV}_{\mathrm{CL}}$ values are 8.76 and 28.675 , respectively (Table 2). Moreover, the chromosome number of the population from Çanakkale (ISTE 102330 ) is $2 n=24$, triploid. Its karyotype formula is $2 n=3 \mathrm{x}=20 \mathrm{~m}+4 \mathrm{~m}-\mathrm{SAT}=24$. Its chromosome lengths range from 1.20 to $3.06 \mu \mathrm{m}$ and its $\mathrm{M}_{\mathrm{CA}}$ and $\mathrm{CV}_{\mathrm{CL}}$ values are 9 and 28.75, respectively (Table 1).

The chromosome number of this species has been previously reported as $2 n=16$ and $2 n=32$ (Richards 1969; Brullo \& al. 1997).

\section{Results and Discussion}

The karyological studies revealed that the basic chromosome number of Taraxacum is $\mathrm{x}=8$. In the literature, satellite chromosomes have been observed in some species (Erlandsson, 1939; Singh \& al. 1974; Krahulcova, 1993; Sato \& al. 2007; Grzesiuk \& al. 2008; Fazili \& al. 2011; Kula \& al. 2013). According to Mogie \& Richards (1983), satellite chromosomes are absent from the most primitive sections of Taraxacum, which are geographically distributed between the Mediterranean Region and Central Asia. Plants in these sections are characterised by large, uniform and metacentric chromosomes and are diploid. 
Table 1. Karyological features of studied Taraxacum species. CLR, chromosome length range; THL, total haploid chromosome length; $\mathbf{M}_{\mathbf{C A}}$, mean centromeric asymmetry; $\mathbf{C V}_{\mathbf{C L}}$, variation coefficient of chromosome length; KF, karyotype formula.

\begin{tabular}{|c|c|c|c|c|c|c|}
\hline Taraxacum species & $2 n$ & $\operatorname{CLR}(\mu \mathrm{m})$ & $\begin{array}{l}\text { THL } \\
(\mu \mathrm{m})\end{array}$ & $\mathbf{M}_{\mathbf{C A}}$ & $\mathrm{CV}_{\mathrm{CL}}$ & KF m-SAT \\
\hline \multicolumn{7}{|l|}{ Sect. Erythrosperma } \\
\hline T. aznavourii & 24 & $1.35-2.81$ & 17.46 & 20.18 & 19.343 & $16 \mathrm{~m}+2 \mathrm{~m}-\mathrm{SAT}+6 \mathrm{sm}$ \\
\hline T. buttleri & 24 & $0.50-0.99$ & 5.595 & 11.43 & 22.541 & $20 \mathrm{~m}+1 \mathrm{~m}-\mathrm{SAT}+3 \mathrm{sm}$ \\
\hline T. gracilens & 24 & $1.12-2.12$ & 12.916 & 22.98 & 18.141 & $18 m+6 m$ \\
\hline T. pseudobrachyglossum & 24 & $1.07-1.72$ & 10.725 & 5.97 & 15.365 & $24 \mathrm{~m}$ \\
\hline T. turcicum & 24 & $1.16-3.03$ & 16.259 & 23.53 & 30.667 & $13 \mathrm{~m}+2 \mathrm{~m}-\mathrm{SAT}+9 \mathrm{sm}$ \\
\hline T. waltheri & 24 & $1.10-2.29$ & 13.719 & 16.28 & 21.034 & $20 \mathrm{~m}+1 \mathrm{~m}-\mathrm{SAT}+3 \mathrm{sm}$ \\
\hline \multicolumn{7}{|l|}{ Sect. Palustria } \\
\hline T. scaturiginosum & 24 & $1.02-2.02$ & 11.431 & 9.09 & 25.819 & $24 \mathrm{~m}$ \\
\hline \multicolumn{7}{|l|}{ Sect. Scariosa } \\
\hline T. aleppicum & 32 & $0.67-1.49$ & 9.459 & 11.86 & 21.649 & $28 \mathrm{~m}+4 \mathrm{sm}$ \\
\hline T. hellenicum & 32 & $1.15-2.38$ & 14.178 & 8.99 & 19.631 & $30 \mathrm{~m}+2 \mathrm{~m}-\mathrm{SAT}$ \\
\hline T. hyberniforme & 32 & $1.36-2.62$ & 15.974 & 7.00 & 20.316 & $27 \mathrm{~m}+5 \mathrm{~m}-\mathrm{SAT}$ \\
\hline T. hybernum & 32 & $1.66-2.98$ & 19.979 & 14.86 & 16.324 & $22 \mathrm{~m}+2 \mathrm{~m}-\mathrm{SAT}+8 \mathrm{sm}$ \\
\hline \multirow{2}{*}{ T. minimum } & 24 & $1.20-3.06$ & 16.952 & 9.00 & 28.75 & $20 \mathrm{~m}+4 \mathrm{~m}-\mathrm{SAT}$ \\
\hline & 32 & $1.06-3.21$ & 17.305 & 8.76 & 28.675 & $19 \mathrm{~m}+5 \mathrm{~m}-\mathrm{SAT}+8 \mathrm{sm}$ \\
\hline
\end{tabular}

Satellite chromosomes have not been observed in sections: Spectabilia, Alpina and Celtica. These sections, however, have been reported to possess chromosomes that carry at least one subterminal NOR (nucleolar ratio) region. A satellite chromosome has been observed in each haploid chromosome set of plants in sections: Macrocornuta, Ceratophora, Mongolica, Tibetana, Parvula, Kashmirana, Erythrocarpa and Palustria. In section Hamata, two satellite chromosomes are found in each triploid cell. The number of chromosomes with the satellites is highly variable in sections Alpestria, Fontana, Obliqua, Erythrosperma, Naevosa, Crocea and may vary even at the same foci and even at the same root (Mogie \& Richards 1983). In our study, we observed satellites in the karyotypes of $T$. aznavourii, T. buttleri, T. hellenicum, T. hyberniforme, T. hybernum, T. minimum, T. turcicum and T. waltheri (sect. Erythrosperma and Scariosa). In the karyotype of T. scaturiginosum (sect. Palustria) satellites were not observed. Section Scariosa generally comprises tetraploid species in this study. The other sections investigated in this study comprise triploid species. Previous studies on the karyology of Taraxacum were based on chromosome number. Recently, however, the karyotype formula with the chromosome number has been reported (Gedik \& al. 2014; Sato \& al. 2012, 2015).

Gedik \& al. (2014) reported karyotype formula and THL of T. bellidiforme Van Soest., T. revertens G. Hagl. beside the chromosome numbers. Satellites are seen in these species. The chromosome numbers are found $2 n=24$ for T. bellidiforme; $2 n=24$ and $2 n=32$ for T. revertens. The THL values of $T$. bellidiforme and T. revertens are 28.56 and 32.67 , respectively. Intrachromosomal asymmetry index and interchromosomal karyotype asymmetry indexes are also calculated in their study. Fazili \& al. (2011) found chromosome number of Taraxacum officinale of Kashmir as a triploid $(2 n=3 \mathrm{x}=24)$ with and it shows that the karyotype exhibits Stebbins IA class of asymmetry, which is the most symmetrical 


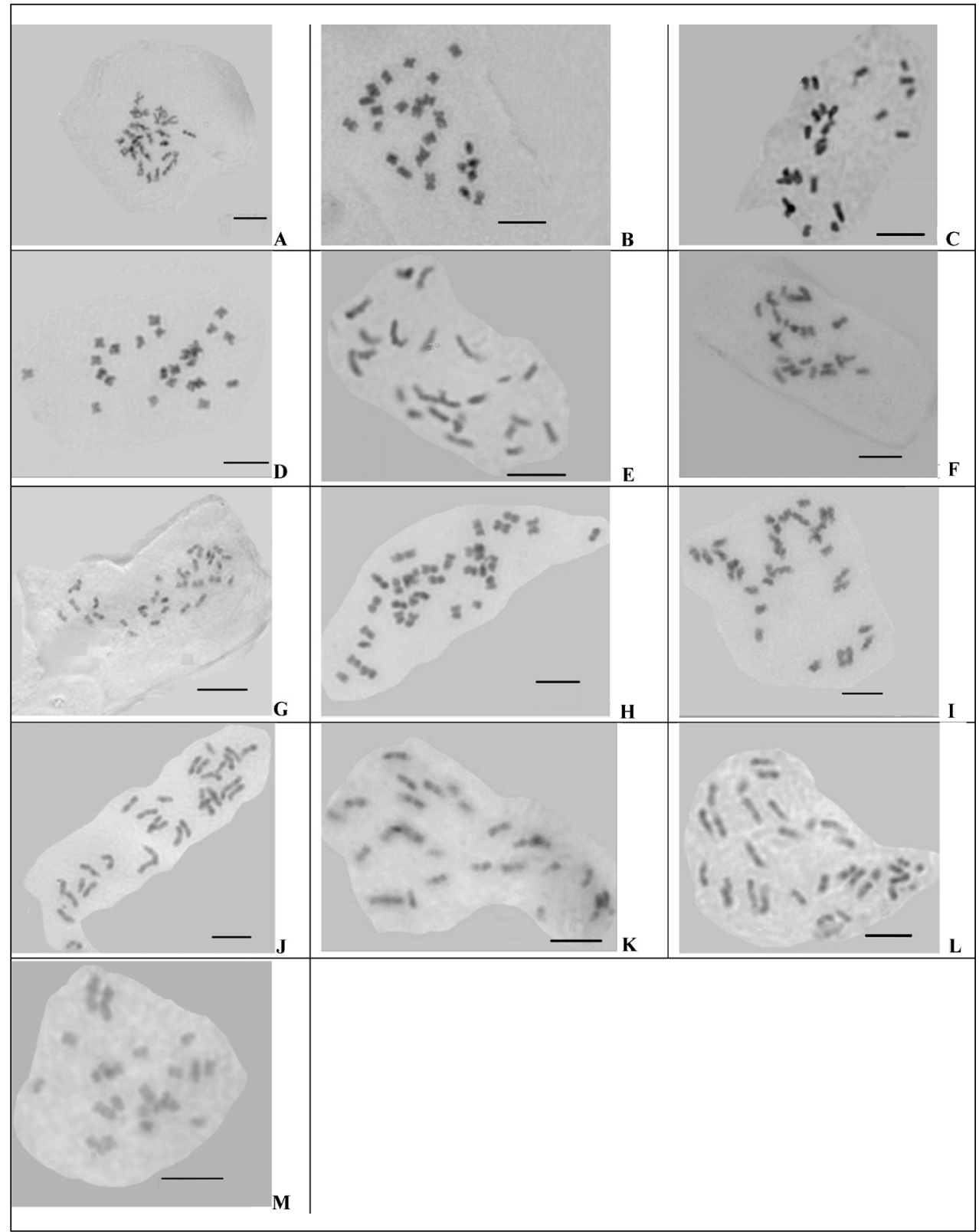

Fig. 1. Mitotic karyotypes of 12 Taraxacum species: A, T. aznavourii, $2 n=3 \mathrm{x}=24$ (ISTE 101782); B, . buttleri, $2 n=3 \mathrm{x}=24$ (ISTE 102545); C, T. gracilens, $2 n=3 \mathrm{x}=24$ (ISTE 101779); D, $T$. pseudobrachyglossum, $2 n=3 \mathrm{x}=24$ (ISTE 102404); E, T. turcicum, $2 n=3 \mathrm{x}=24$ (ISTE 101772); F, $T$. waltheri, $2 n=3 \mathrm{x}=24$ (ISTE 107341); $\mathbf{G}$, T. aleppicum, $2 n=4 \mathrm{x}=32$ (ISTE 102302); H, T. hellenicum, $2 n=4 \mathrm{x}=32$ (ISTE 102324); I, T. hyberniforme, $2 n=4 \mathrm{x}=32$ (ISTE 102310); J, T. hybernum, $2 n=4 \mathrm{x}=32$ (ISTE 102319); K \& L, T. minimum, $2 n=3 \mathrm{x}=24$ (ISTE 101811) $\& 2 n=4 \mathrm{x}=32$ (ISTE 102330); M, T. scaturiginosum, $2 n=3 \mathrm{x}=24$ (ISTE 102400). - Scale bars $=5 \mu \mathrm{m}$. 


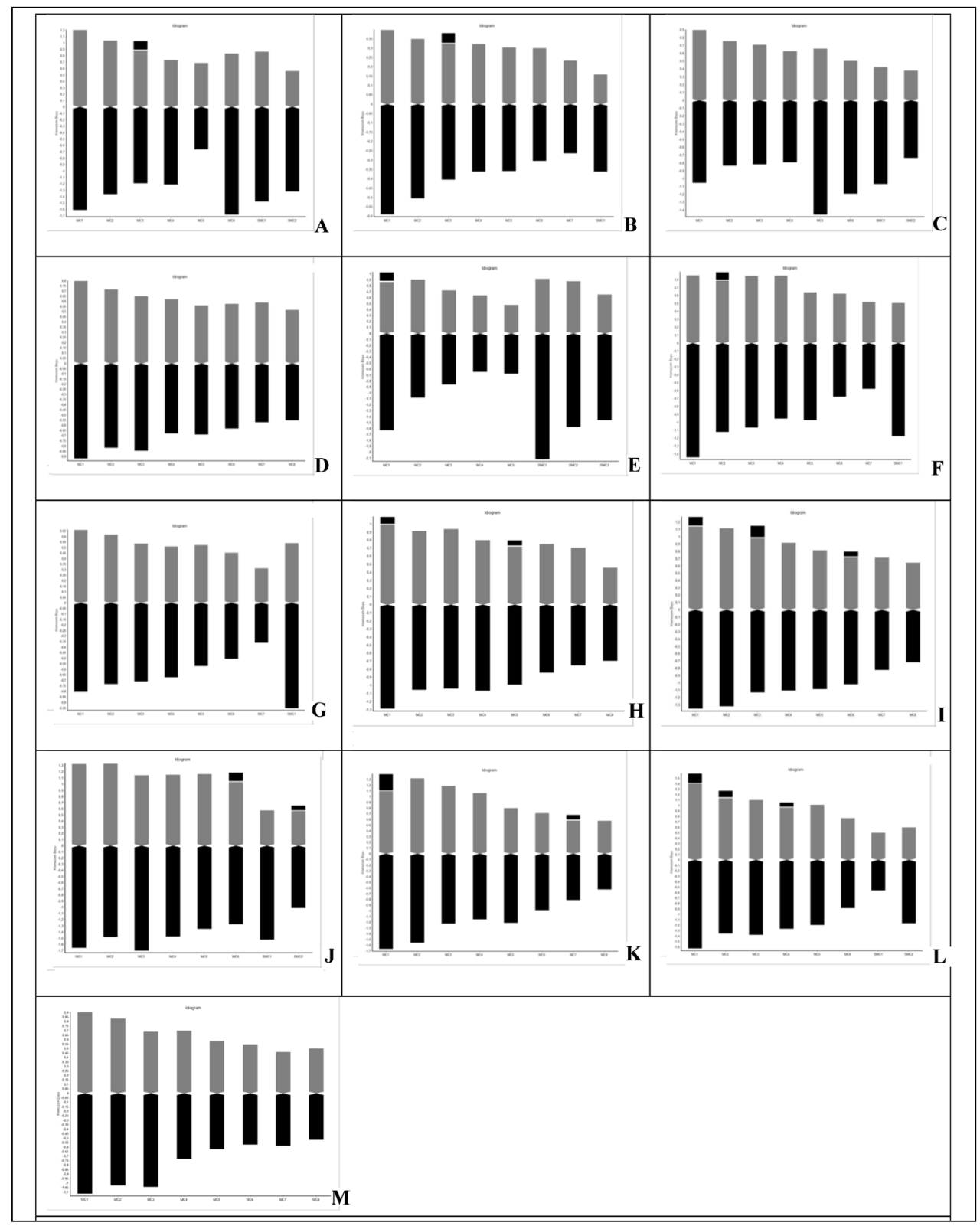

Fig. 2. Idiograms of 12 Taraxacum species: A, T. aznavourii, $2 n=3 \mathrm{x}=24$ (ISTE 101782); B, T. buttleri, $2 n=3 \mathrm{x}=24$ (ISTE 102545); C, T. gracilens, $2 n=3 \mathrm{x}=24$ (ISTE 101779); $\mathbf{D}$, T. pseudobrachyglossum, $2 n=3 \mathrm{x}=24$ (ISTE 102404); E, T. turcicum, $2 n=3 \mathrm{x}=24$ (ISTE 101772); F, T. waltheri, $2 n$ $=3 \mathrm{x}=24$ (ISTE 107341); G, T. aleppicum, $2 n=4 \mathrm{x}=32$ (ISTE 102302); H, T. hellenicum, $2 n=4 \mathrm{x}$ $=32($ ISTE 102324); I, T. hyberniforme, $2 n=4 \mathrm{x}=32$ (ISTE 102310); J, T. hybernum, $2 n=4 \mathrm{x}=32$ (ISTE 102319); K \& L, T. minimum, $2 n=3 \mathrm{x}=24$ (ISTE 101811) $\& 2 n=4 \mathrm{x}=32$ (ISTE 102330); M, T. scaturiginosum, $2 n=3 \mathrm{x}=24$ (ISTE 102400). 
class and considered as primitive. Mártonfiová (2013) reported different TCL (total chromosome length) values for different c-metaphases coming from one meristem of T. linearisquameum Soest.

In this study, the detailed karyotypes of all studied species are provided for the first time. The previously reported chromosome numbers of T. buttleri, T. turcicum and $T$. waltheri (sect. Erythrosperma) correspond with our results of $2 n=24$. In this study, the chromosome numbers of the other three members of section Erythrosperma that are $T$. aznavourii, T. gracilens and T. pseudobrachyglossum are reported for the first time. Similar to other members of section Erythrosperma, T. aznavourii, T. gracilens and $T$. pseudobrachyglossum have a chromosome number as $2 n=24$. As previously reported in the literature, we found that the chromosome number of $T$. scaturiginosum (sect. Palustria), is $2 n=24$; however, the chromosome number of this species has also been reported as $2 n=32$ (Rice \& al. 2014; Richards, 1969). We found that the chromosome number of T. aleppicum and T. hellenicum (sect. Scariosa), is $2 n=32$, as previously reported by Doll (1976a). The chromosome number of $T$. hybernum was formerly reported as $2 n$ $=24$ and 32 (Doll, 1975). In this study, however, the chromosome number of this species is $2 n=32$. The chromosome number of T. minimum has been reported as $2 n=16$ and $2 n$ $=32$ (Richards 1969; Brullo \& al. 1997). The first record $(2 n=16)$ indicated that the species is sexual. However, given that one species cannot simultaneously contain sexual and apomictic individuals; this result was likely caused by misidentification. In this study, we found that the chromosome numbers of these species are $2 n=24$ and $2 n=32$.

Recent studies have reported $\mathrm{M}_{\mathrm{CA}}$ (mean centromeric asymmetry) values in addition to $\mathrm{CV}_{\mathrm{CL}}, \mathrm{CV}_{\mathrm{CI}}$. The $\mathrm{CV}_{\mathrm{CL}}$ values found in this study ranged from 15.365 to 30.667. Based on $\mathrm{M}_{\mathrm{CA}}$ and $\mathrm{CV}_{\mathrm{CL}}$ values, T. pseudobrachyglossum has the most symmetric karyotype, whereas T. turcicum has the most asymmetric karyotype. $\mathrm{M}_{\mathrm{CA}}$ and $\mathrm{CV}_{\mathrm{CL}}$ are positively correlated.

\section{Acknowledgement}

This work was supported by Scientific Research Projects Coordination Unit of Istanbul University. Project number: 26212 and BEK-2016-21308.

\section{References}

Brullo, S., Guglielmo, A., Pavone, P. \& Terrasi, M. C. 1997: Reports (885-898). [In Kamari, G., Felber, F. \& Garbari, F. (eds), Mediterranean chromosome number reports -7]. - Fl. Medit. 7: 267-275.

Dijk, P. J. van, 2003: Ecological and evolutionary opportunities of apomixes: insights from Taraxacum and Chondrilla. - Phil. Trans. R. Soc. Lond. B 358: 1113-1121.

-, Jong, H., Vijverberg, K. \& Biere, A. 2009: An apomixis-gene's view on dandelions. - Pp. 475495. In: Schön I, Martens K, Dijk P. J. van (eds), Lost Sex: The Evolutionary Biology of Parthenogenesis.

Doll, R. 1975: Cytotaxonomische Beiträge zur Taraxacum - Flora der Türkei. - Plant Syst. Evol. 123: 199-212.

- 1976a: Die Section Scariosa H.-M. emend. Dahlst. der Gattung Taraxacum. - Feddes Repert. 87: 553-585. 
- 1976b: Weitere cytotaxonomische beitrage zur Taraxacum- Flora der Türkei. - Pl. Syst. Evol. 125: $21-27$.

Drábková, L. Z., Kirschner, J., Štěpánek, J., Závesky, L. \& Vlcek, C. 2009: Analysis of nrDNA polymorphism in closely related diploid sexual, tetraploid sexual and polyploid agamospermous species. - Plant Syst. Evol. 278: 67-85.

Erlandsson, S. 1939: The chromosome numbers of some Taraxacum species. - Bot. Notiser, Booklet 1: 261-264.

Fazili, K. M., Ali, Y., Hussain, S. S., Andrab, A. \& Wafai, B. A. 2011: Karyotype of apomictic Dandelion (Taraxacum officinale), a wild plant with high medicinal value. - Recent Res. Sci. Technol. 3: 118-121.

Gedik, O., Kıran, Y. \& Türkoğlu, İ. 2014: Taraxacum bellidiforme ve Taraxacum revertens endemik türlerinin karyolojik yönden araştırılması. - Marmara Üniversitesi Fen Bilimleri Dergisi 26: 121-126.

Grzesiuk, A., Marciniuk, J. \& Marciniuk, P. 2008: Chromosomal diversity among Polish origin species of Taraxacum genus. - Electr. J. Pol. Agric. Univ. 11.

Kirschner, J. \& Štěpánek, J. 1985: Taraxacum hoppeanum and its allies (Studies in Taraxacum 4). Preslia 57: 111-134.

— \& - 1994: Clonality as a part of the evolution process in Taraxacum. - Folia Geobot. 29: 265-275.

— \& - 1996: Modes of speciation and evolution of sections in Taraxacum. - Folia Geobot. Phytotax. 31: 415-426.

— \& - 1998: A revision of Taraxacum Sect. Piesis (Compositae). - Folia Geobot. 33: 391-414.

— \& - 2012: A taxonomic revision of Taraxacum sect. Erythrosperma (Compositae - Lactuceae) in Corsica. - Feddes Repert. 123: 139-176.

—, - , Tichy, M., Krahulcovă, A., Kirschnerovă, L. \& Pellar, L. 1994: Variation in Taraxacum bessarabicum and allied taxa of the section Piesis (Compositae): allozyme diversity, karyotypes and breeding behaviour. - Folia Geobot. Phytotax. 29: 61-83.

Krahulcova, A. 1993: New chromosome numbers in Taraxacum with reference to SAT-chromosomes. - Folia Geobot. Phytotax. 28: 289-294.

Kula, A., Grabowska-Joachimiak, A., Kasjaniuk, M., Legutko, J., Marciniuk, P. \& Musiał, K. 2013: Chromosome numbers in 10 Taraxacum species from Poland. - Acta Biol. Cracov. Bot. 55: 153-157.

Mártonfiová, L. 2013: A method of standardization of chromosome length measurement. Caryologia 66: 304-312.

Mogie, M. \& Richards, A. J. 1983: Satellited chromosomes, systematics and phylogeny in Taraxacum (Asteraceae). - Pl. Syst. Evol. 141: 219-229.

Rice, A., Glick, L., Abadi, S., Einhorn, M., Kopelman, N. M., Salman-Minkov, A., Mayzel, J., Chay, O. \& Mayrose, I. 2014: The Chromosome Counts Database (CCDB) - a community resource of plant chromosome numbers. - New Phytologist, doi: 10.1111/nph.13191

Richards, A. J. 1968: The biosystematics of Taraxacum. Ph.D. Thesis, University of Durham.

- 1969: Reports. [In: Löve, A. (ed.), IOPB Plant chromosome number reports XXII]. - Taxon 18: 560-562.

- 1973: The origin of Taraxacum agamospecies. - Bot. J. Linn. Soc. 68: 189-211.

- 2003: Apomixis in Flowering Plants: An Overview. - Phil. Trans. R. Soc. Lond. B 358: 1085-1093.

Sato, K., Iwatsubo, Y. \& Naruhashi, N. 2007: Chromosome Studies of Native Lowland Diploid Species of Taraxacum (Asteraceae) in Japan. - Cytologia 72: 309-317.

—, Yamazaki, T. \& Iwatsubo, Y. 2012: Karyotypes of Taraxacum laevigatum (Asteraceae) in Japan. - Cytologia 77: 211-214. 
—, — \& - 2015: Karyotype Analysis of Three Alpine Taraxacum Species (Asteraceae) in Japan. Cytologia 80: 489-493.

Singh, D., Kaul, V. \& Dathan, A. S. R. 1974: Cytological studies in genus Taraxacum Weber. Proceedings of the Indian Academy of Sciences - Section B 80: 82-91.

Valentine, D. H. \& Richards, A. J. 1967: Sexuality and apomixis in Taraxacum. - Nature 214: 114.

Addresses of the authors:

Bahar Gürdal $^{1}$ \& Neriman Özhatay ${ }^{2}$,

${ }^{1}$ Department of Pharmaceutical Botany, Faculty of Pharmacy, Istanbul University, Istanbul, Turkey. E-mail: bahar.gurdal@istanbul.edu.tr

${ }^{2}$ Faculty of Pharmacy, Eastern Mediterranean University, Famagusta, N. Cyprus. 